\title{
The Relationship between Social Stigma and Brexit of European Teachers in the United Kingdom: The Inquiry of Sociocultural and Psychological Racism
}

\author{
Luis Miguel Dos Santos
}

Woosong University, 196-5 Jayang Dong,

Dong Gu, Daejeon, South Korea

DOI: https://doi.org/10.36941/jesr-2021-0124

\section{Abstract}

Due to the development of the national policies and Brexit in the United Kingdom, teachers from European Union may experience bias and difficulties due to their background and status. From the sociology of education perspective, the researcher employed the stigma approach and the sociocultural and psychological racism theory as the theoretical frameworks to understand how experienced European teachers who lived in the United Kingdom describe their experiences. The phenomenological design with two sessions of in-depth interview tool was employed to recruit 86 participants all around the United Kingdom. The results indicated that workplace bullying, discrimination and stigma due to nationality, and limited promotion opportunities were key concerns. The outcomes of this study captured the contemporary situation, stigma, social bias and discrimination problems based on the people who have settled in the UK for at least two decades. Policymakers, government leaders, human resources professionals, social caring professionals and researchers may take this study as the opportunity to polish and reform their community.

Keywords: Brexit; discrimination; European Union; Freedom of Movement; neo-racism; sociocultural and psychological racism; stigma; teacher's professional development; United Kingdom

\section{Introduction and Background}

\subsection{The research background: The social background and situation}

From the sociology of education perspective, the researcher indicated that social stigma, social bias, and national policies might influence teachers' experiences (i.e. both teaching and living) in the region and country (Ahmed et al., 2020; Dos Santos, 2020c). Due to the freedom of movement in the European Union (EU), EU residents may live in any member states without any working visa applications and related materials. However, EU residents may need to apply for additional working visas and permit for career development in the United Kingdom (UK) due to the recent national policies.

However, the UK officially left the EU at the end of January 2020 following the referendum results, in which $52 \%$ of UK residents advocated that the nation should leave the EU. Prime Minister Johnson promised that the UK would fully leave the EU by the end of 2020 after the transition period 
expired. Many UK residents believed that EU residents take advantage of the UK's public funds and the benefits, education, retirement, and public health systems (Welfens, 2016). In other words, more than half of the UK residents disagreed with the EU Freedom of Movement policy, which allowed EU citizens to enter the UK without restrictions. Based on the current conflicts between the UK and the EU, recently, EU residents who are currently living and investing their career development and life experiences in the UK may face stigma and bias due to their nationality, language accent, skin colour, and place of origin (Mindus, 2017).

Although the UK joined the EU on the $1^{\text {st }}$ January 1973, many UK residents disagreed with some EU policies, such as the Freedom of Movement. The Freedom of Movement policy allowed EU citizens to reside in any of the member states without restrictions. As many EU blue-collar workers and white-collar professionals entered the UK, opportunities have been taken. As a result, the individuals from the EU that have been stigmatised may remain, and stigma may continue to be applied to new members from the EU who join the UK even with professional registration.

For more than two decades, individuals who have resided in the UK were continually labelled and discriminated against according to their nationality, language accent, skin colour, place of origin, and occupation. The stigma and labels became more prominent after the referendum, in which more than half of the British voters advocated leaving the EU. The predominant individuals within society will be considered as the majority. Although people of colour born and raised in the UK should be considered part of the majority, communities of colour are considered minorities due to their skin colour (Bruzelius, 2019).

Teachers who are specialised in supporting certain subject matters were labelled. A study (Freer \& Evans, 2019) found that physical education, music, art and design, and foreign languages were neglected due to their subject matters. As a result, teachers indicated that some administrators might allocate resources based on subject matters instead of the needs. Another study (Petrenko et al., 2020; Zhao \& Ko, 2018) found that the classrooms and supporting materials were unfairly distributed to vocational-oriented subjects.

The nationality and visa status of a person can cause stress, stigma, and bias. One study (Dos Santos, 2020a) found that a group of teachers decided to quit their school and leave their host country due to the discrimination they experienced based on their visa status (i.e. foreigner) and personal characteristics (i.e. skin colour). Workplace bullying in school and environmental discrimination from the members of the public always cause stress due to stigma and bias. As a result, some decided to leave their host country because of discrimination and low self-efficacy (Jochum et al., 2017; Runhaar \& Sanders, 2016; Yost, 2006).

The purpose of the study

Based on the above social background, a large number of European citizens, legal residents, and professional workers are currently living and working in the UK for personal and career developments, particularly qualified teachers (Murray et al., 2008). In this study, the researcher employed qualified European teachers as the sample to understand the experiences and behaviours in the United Kingdom during the transition period in the UK.

Studies have not accounted for shifts based on the current Brexit situation, shifts that are changing the overall background and political issues in the UK-EU relationship, in particular, the problems of the strong workforce and occupational relationships between the UK and the EU that have been established for more than four decades. The shared and engaged economy and governmental system offered opportunities for researchers to understand how stigma and bias influenced EU citizens' daily life in the UK after the referendum and the Brexit, particularly European qualified teachers (Wyse \& Ferrari, 2015). The following two research questions guided the study,

1. How would EU citizens and experienced teachers who lived in the UK for more than two decades describe their experiences after the referendum about stigma and bias, particularly in their workplace environment? 
2. How would the referendum results impact their role as EU citizens and experienced teachers in the UK after the referendum and during the transition period, particularly in their workplace environment?

The researcher explored these research questions through the phenomenological approach of experienced EU teachers who have lived in the UK for more than two decades. The residents in the home country stigmatise foreign communities. Although the EU encouraged Freedom of Movement, some EU member states continued to require passport control. Therefore, from the perspectives of some long-term EU teachers in the UK, the results of this study outline the stigma and bias that EU teachers faced. More importantly, the results provide a blueprint for policymakers, government leaders and researchers to reform the current residential policies and human resources planning for EU citizens and teachers who face stigma and bias after the transition period.

\subsection{The theoretical frameworks}

Stigma and biases are some of the key concerns in this study. Therefore, the researcher employed two theoretical frameworks and theories in order to seek the understanding and answer from the research questions, including the stigma theory (Tajfel, 2010) and the sociocultural and psychological racism (Dos Santos, 2019d, 2020b; Lee et al., 2017; Lee, 2007).

First of all, the stigma based on a person's occupation and nationality is not uncommon and is documented widely in academic literature. Tajfel (Tajfel, 2010) argued that stigma is usually concerned with the sociocultural context, gender, sexual orientation, religion, skin colour, nationality, place of origin, language, health, or occupation of individuals or groups in the majority and predominate communities. Stigma usually occurs in schools, workplaces, health contexts, and living communities. If individuals are discriminated against, they will recognise that the discrimination was in response to their characteristics.

Language accent is the source of stigma. Many have advanced proficiency in the English language due to their efforts to invest in their personal development when in the UK. However, their accent often cannot be changed as English is an additional language. Language-oriented stigma is not uncommon in the UK. A study (Dunmore, 2017) found that students and teachers from Scotland were discriminated against by English people due to their Scottish accents. In the field of education, stigma is not uncommon. People who are not home or native teachers are usually stigmatised as many managements prioritise native/home teachers. Pre-service and supporting workers provide the additional workforce that schools and departments desire, but many report discrimination and stigma due to their status.

Second, sociocultural and psychological racism is one of the newest theories developed by Dos Santos (Dos Santos, 2019b, 2020b). The sociocultural and psychological racism indicated that individuals and groups might receive discrimination and bias based on their non-biological characteristics. In other words, unlike traditional racism, individuals and groups may be discriminated against based on their race and skin colour. The sociocultural and psychological racism advocated two directions, including the psychological and internal factors, such as 1) religious and philosophical behaviours and 2) personal beliefs; and social, personal, and external factors, such as 1) place of origin, 2) age, 3) social behaviours, 4) cultural characteristics, 5) spoken languages, 6) sexual orientation, and 7) career development. Figure 1 outlines the ideas of the sociocultural and psychological racism. 


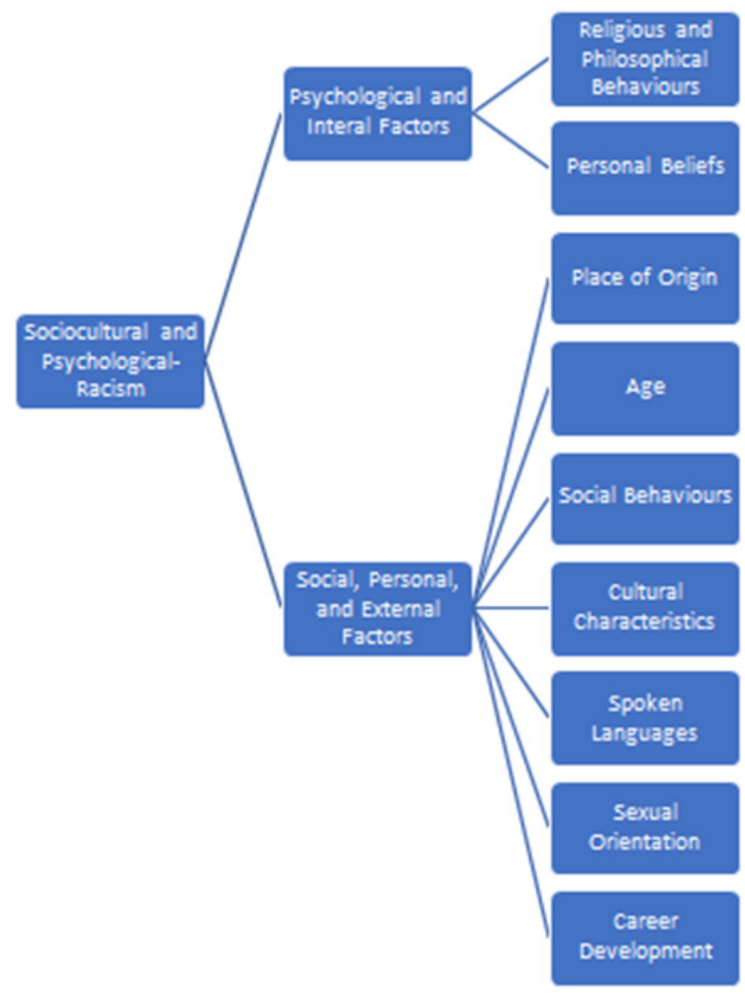

Figure 1: The sociocultural and psychological racism

\subsection{Definition of terms}

Brexit: Brexit also refers to the political movement and decision of the British Exit. Based on the referendum result, the United Kingdom decided to leave the European Union at 23:00 on $31^{\text {st }}$ January 2020 (GMT). After this time, the United Kingdom was no longer a member state of the European Union.

European Union: European Union also refers as the EU. The European Union is a political and economic union of 27 member states in the European continent (i.e. formerly 28 member states before the Withdrawal from the United Kingdom).

Freedom of Movement: Based on Article 45 of the Treaty on the Functioning of the European Union and European Union secondary legislation and the Case law of the Court of Justice. Citizens of the European Union may live, work, study in any member states without limitations.

Referendum: Referendum refers to the voting results from the British Exit movement. $52 \%$ of UK residents advocated that the United Kingdom should leave the European Union.

Transition Period: The United Kingdom has officially left the European Union at 23:00 on $31^{\text {st }}$ January 2020 (GMT). However, the British government and the European Union agreed that both sides should remain the same, such as law and immigration policies, until the end of the $31^{\text {st }}$ December 2020.

United Kingdom: The United Kingdom also refers as the UK. It is a kingdom with four countries, including England, Wales, Scotland, and Northern Ireland. 


\section{Methodology}

\subsection{The application of the phenomenological analysis}

The current study employed the phenomenological analysis (Moustakas, 1994) as the research design. The research design followed the qualitative research study as this study seeks to understand the lived experiences, personal sharing, and stories of the individuals and groups. A previous study (Dos Santos, 2019a) examined and explored the lived experiences of school teachers used the qualitative research method to understand the background and sharing of the individuals fully. The phenomenological analysis is useful in gaining first-hand and in-person data from the individuals' own conception and sharing of the experiences and lived stories.

Phenomenological analysis may make a strong direction of how the individuals make sense of their social world and inner understanding. The application of the phenomenological analysis is to remain the focus and direction of the research and avoid bias and subjective scope by the researcher(s) (Creswell, 2012; Merriam, 2009). As a result, this phenomenological study allowed the researcher to collect how secondary school teachers describe their experiences as European citizens in the UK.

\subsection{Participants and recruitments}

86 participants currently teaching at one of the primary and secondary school environments in the UK were invited. Based on the purposes of this study, the researcher only invited people who met the following criteria,

- $\quad$ hold one of the EU passports

- $\quad$ achieve their Qualified Teacher Status (QTS) or equivalent

- live in the UK for at least two decades

- consider the UK as their home

Snowball strategy was employed for recruitment (Merriam, 2009). Based on the networks, the researcher invited three participants who met the criteria. However, three participants' lived stories could not satisfy the research purposes. First, the researcher sent an email invitation to the participants. If the participants agree to the invitation, the participants should respond. The researcher arranged the interview sessions. After the sessions, the participants were encouraged to refer any potential participants. After rounds of the referral, a total of 86 participants joined.

\subsection{Data collection}

The open-ended and semi-structured interview tool was employed to collect data (Merriam, 2009). The individuals may share their lived stories, life experiences, understanding, personal goals, and environmental feelings as experienced teachers living in the UK for more than two decades. The general inductive approach (Thomas, 2006) was employed for qualitative data collection and analysis. Interview questions were developed based on the ideas of discrimination, stigma and bias, and the objectives of the study.

The researcher invited each for two sessions. Although the researcher did not know each other, conducting two-round sessions allowed us to know each other. Each session lasted from 49 to 81 minutes. In addition to these sessions, to confirm the validity of the data, the researcher sent the related transcripts to each for confirmation. With a brief member checking session, all agreed on their sharing. Although the native language(s) of these participants are not English due to their place of origin, all have a supreme level of language proficiency. Therefore, the sessions were conducted in English. After the data procedure with 172 sessions, a large number of conversations has been collected. However, to report the conversations into a manuscript, the researcher needed to 
transcribe the sharing into the written transcript.

\subsection{Data analysis}

Qualitative researchers advocated that large-size data should be reduced to group the themes and subthemes into meaningful categories. The researcher employed the open-coding strategy to narrow down the data into first-level themes and subthemes. Based on the open-coding strategy, the researcher could narrow down the raw materials into 20 themes. However, it is impossible to report a large number of themes. Therefore, the researcher needed to conduct the axial-coding strategy. The researcher eventually categorised the information into three themes as the second-level themes and subthemes.

\subsection{Data protection}

The protection of personal data and information is the most important factor. Therefore, the researcher stored both signed and unsigned consent forms, voiced messages, written transcripts, personal contacts, computer, and related materials in a password-protected cabinet. Only the researcher has the right to read the data and materials. In addition, all participants were assigned a pseudonym. After the researcher completed the data analysis, the researcher destroyed the related materials for personal privacy.

\section{Results and Discussions}

During interview sessions, the participants answered the same interview protocol and open-ended and semi-structured interview questions about their experiences after the 2016 referendum as EU citizens and teachers in the UK. Although all participants were experienced, senior-level, and wellestablished teachers at a primary or secondary school in the UK and had been teaching for more than 20 years, their experiences, background, working environment, understanding, community, and personal beliefs are not the same. Therefore, the results highlighted a number of social, cultural, and environmental expectations of the current British factors during the post-Brexit period (i.e. the transition period). Table 1 outlines the themes and subthemes of this study.

Table 1: Themes and Subthemes

\begin{tabular}{|l|}
\hline \multicolumn{1}{|c|}{ Themes and Subthemes } \\
\hline Workplace Bullying: Discriminations and Stigma \\
\hline Discriminations and Stigma due to Nationality \\
\hline Limited Promotion Opportunities \\
\hline
\end{tabular}

\section{1}

Workplace bullying: Discriminations and stigma

Workplace bullying (Dos Santos, 2020a, 2020d) is not unique to the teaching profession or education sector, and gender, age, language, place of origin, visa type, and skin colour could be factors of discrimination, particularly after the UK officially left the EU in early 2020. According to a previous study, Black teachers are routinely discriminated against based on their skin colour, nationality, and even language accent (Dos Santos, 2019b, 2020a). As this study was conducted after the UK officially left the EU, the sharing and opinions mainly focused on how Brexit would influence their roles and positions as citizens of the EU in the UK within the timeframe (i.e. from the period after the 2016 referendum to the transition period) (Hantzsche et al., 2019; Tomlinson, 2019; Welfens, 2016). Although many large cities and metropolitan areas in the UK supported the idea of remaining, many members of suburban and rural communities believed European citizens took away their working 
opportunities ("EU Referendum Results," 2016). The participants, European citizens in the UK, described a number of workplace-bullying situations due to their nationalities and status as European citizens. According to a previous study (Anya, 2018), nationality can be a significant element of discrimination regardless of an individual's professional status and license. For example, even in school environments, many participants stated that their co-workers usually referred to them by the subject they taught rather than by their actual name (i.e. given name and family name). Some accounts of these instances are as follows:

I am a French teacher ... and I have an official name.... Especially after the Brexit Referendum my coworkers and school leaders usually call people by their given name ... but for me, all teachers just call me the French teacher ... not my given name.... I even expressed this issue to the City Council ... but no investigations were conducted. $\left(P \#_{3}\right)$

The Spanish teacher ... the man from Madrid ... this is not uncommon after the 2016 referendum.... I felt so annoyed as this name was given by some of my co-teachers in my school and even school leaders ... they would not use this name in front of me ... but I knew they called me in this way. (P\#33)

...look at that man from Sweden, he is an immigrant from Sweden...we voted him out...I have heard these types of conversations and communications all around rural Wales after the 2016 referendum...but it is normal? I cannot tell...but this is not uncommon in many cities and towns in Wales (P\#85)

Based on the idea of stigma (Tajfel, 2010) and sociocultural and psychological racism (Dos Santos, 2019d, 2020b; Lee et al., 2017; Lee, 2007), many participants have experienced different types of social stigma and discrimination due to their name and place of origin. It is worth noting that the participants from rural communities and places experienced these types of bias significantly after the Brexit decision.

\subsection{Discriminations and stigma due to nationality}

Exceed job responsibilities may create inconvenience and stigma due to the role of the participants. According to many previous studies (Betoret \& Artiga, 2010; Burke et al., 1996; Dos Santos, 2016; Klassen \& Chiu, 2010; Kyriacou, 2001; Yang et al., 2018), overloaded working responsibilities, endless grading, and after-school activities are not uncommon in the field of education and teaching. Many teachers and educators complained about the excessive workload of their classroom management. School leaders are working to make improvements in these areas (Dos Santos, 2016). However, due to the results of the 2016 referendum, a large number of European residents and workers decided to leave the UK due to political unrest, and, as a result, many schools and non-profit organisations experienced human resources shortages due to these career decisions. Unlike financial and business industries, schools usually do not have enough resources to increase salaries to immediately attract additional employees (Doyle et al., 2006). Therefore, due to the limited workforce, individuals who are working need to take on additional responsibilities. However, all the participants understood and accepted these immediate arrangements because of the political unrest.

Firstly, regarding discrimination and stigma (Tajfel, 2010) at the school district-level, all participants indicated that their school districts and head leadership decided not to recruit European teachers after the 2016 referendum. Although no one could point to any evidence from human resources management, all shared similar observations about their experiences. The researcher captured several significant accounts. Two participants stated:

The political unrest was full of discrimination ... we would accept the results from the people and the parliament ... however, many co-workers in my school communities showed discrimination ... for example, they eliminated the recruitment process of the European teachers.... After the 2016 referendum, my school did not recruit any European teachers any more. (P\#22)

...The recruitment is quite serious after 2016...my supervisor told me that they want to recruit English 
teachers first...although the United Kingdom is still a part of the European Union, I can tell many school leadership...keep as away...(P\#75)

Another participant who was teaching in one of the rural school districts in northeast England shared similar feedback:

My school used to like to recruit European teachers for European foreign language subjects, such as Italian, Spanish and French ... but after the 2016 referendum ... my school limited the recruitment of European teachers.... I referred many other European teachers and classmates to the school districts ... however, none received a call for an interview. (P\#41)

Secondly, regarding discrimination and stigma at the school-level, although each teacher took on additional responsibilities because of the human resources shortage, many participants expressed strong negative feedback about the unfairness and workplace bullying due to their European nationalities. Previous studies (Doyle et al., 2006; Mindus, 2017) have indicated that a large number of British people believed European professionals took away their working opportunities. Therefore, many found that British people may discriminate and engage in workplace bullying and negative behaviours toward European professionals (Tomlinson, 2019). The researcher captured several significant accounts of how these negative behaviours caused negative experiences that European teachers experienced. Two participants stated:

As a foreign language teacher in Spanish, my co-workers always looked down on me because my subject is not the most important subject ... from their behaviours and meeting arrangement, you can feel the discrimination as a non-English person ... particularly after the 2016 referendum, they established a virtual wall or border between British and European teachers. (P\#34)

...I teach Spanish...this subject for more than 20 years...I am a part of the United Kingdom and a part of the Scottish community...but after the Brexit, some people...love European residents...but some people dislike us...very much...I can feel the stress and burnout both at school and our living communities...(P\#39)

Another participant also described a group and cohort-like arrangement with their co-workers. For example, they expressed that after the 2016 referendum, local British teachers set up an individual group social media chat without any European teachers. Although such group behaviours and arrangements did not influence their work performance, the social levelling and stigma the participants experienced were quite clear. One individual stated:

No laws or policies could limit how people set up their WhatsApp group chats ... but you can see that British teachers avoid us in their own British chatrooms.... I am not begging to join ... but this stigma is not positive ... under the current transition period, we are excluded from the country. (P\#49)

In short, based on the theoretical frameworks of stigma (Tajfel, 2010) and sociocultural and psychological racism (Dos Santos, 2019d, 2020b; Lee et al., 2017; Lee, 2007), many participants expressed that the 2016 referendum led them to have a number of negative experiences due to the stigma associated with their European status. Although no one could physically point to any evidence of such discrimination and stigma, all expressed that their working environments were negative (Devers et al., 2009). More importantly, many expressed that their nationality (i.e., EU citizens) was always one of the main sources of stigma and social bias.

\subsection{Limited promotion opportunities}

Significant numbers of reports of limited promotion opportunities due to having a European status were shared in the data collection procedure (Dodourova et al., 2020). Based on their background 
and recruitment criteria, all the participants were experienced and senior-level teachers with at least two decades of teaching experience. More than two-thirds of them indicated that they had applied for a promotion in their school or other school districts after the 2016 referendum. However, none received any interview calls or emails. A recent study (Tomlinson, 2019) found that once the Freedom of Movement policy had been introduced, more than a million European residents moved to the UK for career development (Mindus, 2017). As a result, many metropolitan areas and large cities in the UK were developed due to the multicultural human resources (Dodourova et al., 2020). However, the rural communities may not have welcomed these developments, and residents in rural counties disliked the foreign communities based on the principles of protectionism.

Firstly, the participants spoke of discrimination and stigma related to their own in-school promotion prospects. Similar to a previous study (Mccrory \& Thomson, 2019), many expressed that the 2016 referendum limited their career development and promotion opportunities due to their European nationality and the stigma related to this. Many expressed that after 2016, because of the unforeseen residential status and visa arrangements, many school leaders decided not to promote European and Tier 2 visa teachers to any upper-level positions. This was not a singular event, but something that all participants described. For example, one participant stated that:

the committees told me that a junior-level teacher was suitable for the department head position ... I discussed my case with other European and international teachers ... it is not about my qualification and skills, it is about my nationality and visa status ... I don't have a British passport. (P\#68)

One French teacher also indicated that his/her European social status was an obstacle in his/her application to the head teacher's position due to the stigma associated with being a European teacher. The participant said:

Three French senior-level co-workers and one British junior-level teacher applied for the same head teacher's position ... we all applied to be the headteacher in the French department ... but eventually, the junior-level British teacher got the position ... we asked for the reasons why ... the committee told us that our performances and evaluations are lower than those of the British teacher. (P\#2)

Secondly, participants described instances of discrimination and stigma when applying for other positions in the UK. Due to the 2016 referendum, many school districts did not understand how to handle visa issues for both European and international teachers with a Tier 2 working visa. As a result, some committee members may prefer British individuals in order to avoid unforeseen visa applications due to the changeable political landscape. The researcher captured several significant findings in regard to this, with one participant saying:

My headmaster told me that they understood how to manage international teachers who required working Tier 2 visa applications... Under the unforeseen policy changes during that time, many school districts did not understand how to handle the visa or government documents for European teachers ... we are not British, and we are not international professionals ... we are in the middle of stigma. (P\#55)

Another participant who has worked as a searching committee for a teacher's position shared this experience regarding confusion around the visa issue that arose due to the 2016 referendum:

I failed my position, but I worked as a committee member for a junior-level teacher's position ... our school district told us that we should recruit British individuals as a priority due to the unforeseen visa policies.... Only if there were no appropriate applicants...could we interview European teachers as an alternative. (P\#9)

In short, with regard to these themes and subthemes, many participants expressed that the local British residents were afraid that EU citizens would reduce their social benefits and career opportunities due to the large numbers of EU professionals. As a result, more than half of the British 
voters decided to leave the EU. However, many previous studies (Doyle et al., 2006; Duda-Mikulin, 2019) have indicated that the EU workforce and human resources always increase the financial and economic developments of all parts of the UK. However, due to the nature of resource allocation in the country, most of the residents in the UK would not benefit from the development of the economy. It is not hard to believe that due to the unfair nature of resource allocation throughout the UK, many British people expressed negative feelings, stigma, and social bias towards EU citizens (Doyle et al., 2006; Mindus, 2017).

\section{Limitations and Future Research Directions}

Every research study has its limitations. Three limitations have been found in this study. First, the research could only cover EU teachers who are currently living in the UK for more than two decades. However, other professionals, such as health and social caring professionals, may face a similar background and issue due to the political decision from the British government. Therefore, future researchers may take this study as the opportunity and blueprint to investigate the issues for other professionals and occupations.

Second, leaving the EU is one of the significant decisions which always impacted the overall performance, international relations, political management, organisational leadership, human resources management, workforce arrangement and even human behaviours. As this research study focused on the targeted period (i.e. after the 2016 referendum and before the expiration of the Transition Period), some significant sharing and data information may be missed. Therefore, once the Transition Period has been expired, researchers should conduct a similar research study in order to investigate the behaviours and developments with a group of people with a similar background.

Third, although EU citizens and teachers face discrimination, stigma and social biases due to the 2016 referendum, many international professionals and visa holders may face a similar background. Therefore, future research studies may cover these individuals and groups in the UK in order to expand the research study and understand the holistic problem in the UK.

\section{Conclusion}

To the best of the knowledge, this is one of the first qualitative research studies that is based on the understanding, sharing, lived stories, and lived experiences of experienced teachers who are currently living in the UK as EU citizens for more than two decades during the targeted period (i.e. after the 2016 referendum and before the expiration of the Transition Period). Although the UK always promotes itself as an open-minded and welcoming country where international professionals and experts may settle and promote their life, family and career development, most of the participants in this study advocated that the British residents always label and categorise them based on their nationality and language accent. The results of this study captured the contemporary situation, stigma, social bias and discrimination problems based on the people who have settled in the UK for at least two decades. Policymakers, government leaders, human resources professionals, social caring professionals and researchers may take this study as the opportunity to polish and reform their community due to the political unrest. Otherwise, human resources and the workforce may leave the UK and invest their career development in other countries.

\section{Acknowledgement}

Funding: This research is supported by the Woosong University Academic Research Funding 2021. 


\section{References}

Ahmed, S., Birtel, M. D., Pyle, M., \& Morrison, A. P. (2020). Stigma towards psychosis: Cross-cultural differences in prejudice, stereotypes, and discrimination in White British and South Asians. Journal of Community $\mathcal{E}$ Applied Social Psychology, 30(2), 199-213. https://doi.org/10.1002/casp.2437

Anya, U. (2018). Race and ethnicity in teacher education. In The TESOL Encyclopedia of English Language Teaching (pp. 1-7). John Wiley \& Sons, Inc. https://doi.org/10.1002/9781118784235.eelto673

Betoret, F., \& Artiga, A. (2010). Barriers perceived by teachers at work, coping strategies, self-efficacy and burnout. The Spanish Journal of Psychology, 13(2), 637-654. https://doi.org/10.1017/S1138741600oo2316

Bruzelius, C. (2019). Freedom of movement, social rights and residence-based conditionality in the European Union. Journal of European Social Policy, 29(1), 70-83. https://doi.org/10.1177/0958928718756262

Burke, R. J., Greenglass, E. R., \& Schwarzer, R. (1996). Predicting teacher burnout over time: Effects of work stress, social support, and self-doubts on burnout and its consequences. Anxiety, Stress \& Coping, 9(3), 261-275. https://doi.org/10.1080/10615809608249406

Creswell, J. (2012). Qualitative inquiry and research design: Choosing among five approaches. Sage.

Devers, C. E., Dewett, T., Mishina, Y., \& Belsito, C. A. (2009). A general theory of organisational stigma. Organization Science, 20(1), 154-171. https://doi.org/10.1287/orsc.1080.0367

Dodourova, M., Clarkin, J. E., \& Lenkei, B. (2020). The die is cast: Brexit's influence on student career intentions. Studies in Higher Education, 45(3), 648-664. https://doi.org/10.108o/03075079.2019.1593346

Dos Santos, L. M. (2016). Relationship between turnover rate and job satisfaction of foreign language teachers in Macau. Journal of Educational and Developmental Psychology, 6(2), 125. https://doi.org/10.5539/jedp.v6n2p125

Dos Santos, L. M. (2019a). Recruitment and retention of international school teachers in remote archipelagic countries: The Fiji experience. Education Sciences, 9(2), 132. https://doi.org/10.339o/educscigo20132

Dos Santos, L. M. (2019b). Experiences and expectations of international students at historically black colleges and universities: An interpretative phenomenological analysis. Education Sciences, 9(3), 189. https://doi.org/10.3390/educscigo30189

Dos Santos, L. M. (2020a). Stress, burnout, and turnover issues of Black expatriate education professionals in South Korea: Social biases, discrimination, and workplace bullying. International Journal of Environmental Research and Public Health, 17(11), 3851. https://doi.org/10.3390/ijerph17113851

Dos Santos, L. M. (2020b). The challenging experiences of international students in South Korea: The neo-racism perspective. Universal Journal of Educational Research, 8(12B), 8102-8109. https://doi.org/10.13189/ujer.2020.082612

Dos Santos, L. M. (2020c). Male nursing practitioners and nursing educators: The relationship between childhood experience, social stigma, and social bias. International Journal of Environmental Research and Public Health, 17(14), 4959. https://doi.org/10.339o/ijerph17144959

Dos Santos, L. M. (2020d). Stress, burnout, and low self-efficacy of nursing professionals: A qualitative inquiry. Healthcare, 8(4), 424. https://doi.org/10.3390/healthcare8040424

Doyle, N., Hughes, G., \& Wadensjö, E. (2006). Freedom of movement for workers from central and eastern Europe: Experiences in Ireland and Sweden. https://www.issuelab.org/resources/19070/19070.pdf

Duda-Mikulin, E. (2019). EU migrant workers, Brexit and precarity: Polish women's perspectives from insude the UK. Bristol University Press.

Dunmore, S. S. (2017). Immersion education outcomes and the Gaelic community: identities and language ideologies among Gaelic medium-educated adults in Scotland. Journal of Multilingual and Multicultural Development, 38(8), 726-741. https://doi.org/10.108o/01434632.2016.1249875

EU Referendum Results. (2016). BBC News. https://www.bbc.com/news/politics/eu_referendum/results

Freer, E., \& Evans, P. (2019). Choosing to study music in high school: Teacher support, psychological needs satisfaction, and elective music intentions. Psychology of Music, 47(6), $781-799$. https://doi.org/10.1177/0305735619864634

Hantzsche, A., Kara, A., \& Young, G. (2019). The economic effects of the UK government's proposed Brexit deal. The World Economy, 42(1), 5-20. https://doi.org/10.1111/twec.12770

Jochum, C., Rawlings, J., \& Tejada, A. (2017). The effects of study abroad on Spanish teachers' self-efficacy: A Multiple case study. Frontiers: The Interdisciplinary Journal of Study Abroad, 29(1), 28-45. https://doi.org/10.36366/frontiers.v29i1.384

Klassen, R. M., \& Chiu, M. M. (2010). Effects on teachers' self-efficacy and job satisfaction: Teacher gender, years of experience, and job stress. Journal of Educational Psychology, 102(3), 741-756. https://doi.org/10.1037/aoo19237

Kyriacou, C. (2001). Teacher Stress: Directions for future research. Educational Review, 53(1), 27-35. https://doi.org/10.108o/oo131910120033628 
Lee, J. J. (2007). Bottom line-Neo-racism toward international students. About Campus: Enriching the Student Learning Experience, 11(6), 28-30. https://doi.org/10.1002/abc.194

Lee, J., Jon, J., \& Byun, K. (2017). Neo-racism and neo-nationalism within East Asia. Journal of Studies in International Education, 21(2), 136-155. https://doi.org/10.1177/1028315316669903

Mccrory, M., \& Thomson, T. (2019). The political is personal: Brexit and the career aspirations of Uk undergraduates. Journal of the National Institute for Career Education and Counselling, 42(1), 3-8. https://doi.org/10.20856/jnicec.4202

Merriam, S. B. (2009). Qualitative research: A guide to design and implementation. Jossey Bass.

Mindus, P. (2017). European citizenship after Brexit. Springer International Publishing. https://doi.org/10.1007/9783-319-51774-2

Moustakas, C. (1994). Phenomenological research methods. Sage.

Murray, J., Campbell, A., Hextall, I., Hulme, M., Jones, M., Mahony, P., Menter, I., Procter, R., \& Wall, K. (2008). Mapping the field of teacher education research: Methodology and issues in a research capacity building initiative in teacher education in the United Kingdom. European Educational Research Journal, 7(4), 459474. https://doi.org/10.2304/eerj.2008.7.4.459

Petrenko, L., Kravets, S., Bazeliuk, O., Maiboroda, L., \& Muzyka, I. (2020). Analysis of the current state of distance learning in the vocational education and training institutions. $E_{3} S$ Web of Conferences, 166, 10010. https://doi.org/10.1051/e3sconf/202016610o10

Runhaar, P., \& Sanders, K. (2016). Promoting teachers' knowledge sharing. The fostering roles of occupational selfefficacy and human resources management. Educational Management Administration E Leadership, 44(5), 794-813. https://doi.org/10.1177/1741143214564773

Tajfel, H. (2010). Social identity and intergroup relations. Cambridge University Press.

Thomas, D. R. (2006). A general inductive approach for analysing qualitative evaluation data. American Journal of Evaluation, 27(2), 237-246. https://doi.org/10.1177/1098214005283748

Tomlinson, S. (2019). Education and race from empire to brexit. Policy Press.

Welfens, P. J. J. (2016). Cameron's information disaster in the referendum of 2016: An exit from Brexit? International Economics and Economic Policy, 13(4), 539-548. https://doi.org/10.1007/s10368-016-0361-3

Wyse, D., \& Ferrari, A. (2015). Creativity and education: Comparing the national curricula of the states of the European Union and the United Kingdom. British Educational Research Journal, 41(1), 30-47. https://doi.org/10.1002/berj.3135

Yang, C.-C., Fan, C.-W., Chen, K.-M., Hsu, S.-C., \& Chien, C.-L. (2018). As a happy kindergarten teacher: The mediating effect of happiness between role stress and turnover intention. The Asia-Pacific Education Researcher, 27(6), 431-440. https://doi.org/10.1007/s40299-018-0403-4

Yost, D. S. (2006). Reflection and self-efficacy: Enhancing the retention of qualified teachers from a teacher education perspective. Teacher Education Quarterly, 33(4), 59-76.

Zhao, Y., \& Ko, J. (2018). Workplace learning in the professional development of vocational education teachers. Studia Paedagogica, 23(2), 43. https://doi.org/10.5817/SP2018-2-4 